\title{
Fighting the invisible anaconda amidst a war of conquest: notes of a genocide
}

\author{
Felipe Milanez
}

${ }^{I}$ Associate Professor at the Professor Milton Santos Institute of Humanities, Arts and Sciences (IHAC), Federal University of Bahia (UFBA)

Salvador/BA - Brasil

\begin{abstract}
The conquest of indigenous territories and epidemic diseases have gone hand in hand throughout the history of Brazil. The current new coronavirus pandemic that is devastating indigenous communities follows this violent strategy of conquest. My argument is that structural racism that has led to the death of more than 200 indigenous people in the first months of the pandemic should be seen not as irresponsible acts of omission, but as acts of genocide.
\end{abstract}

Keywords: Indigenous peoples; COVID-19; conquest; genocide; political ecology

São Paulo. Vol. 23, 2020

Debating ideas

The COVID-19 epoch: Interdisciplinary research towards a new just and sustainable ethics

DOI: http://dx.doi.org/10.1590/1809-4422asoc20200116vu2020L3ID 


\section{Introduction: diseases and conquest}

Epidemics and the war of conquest have always gone hand in hand in the history of the invasion and creation of Brazil. From flu, measles, smallpox, viruses and bacteria, to different sorts of diarrhoea, all of these plagues have served the European expansion in Abya Yala. They often erupted in the crowded villages (aldeamentos) built by Jesuit missionaries, such as the smallpox epidemic in 1562/63 in Bahia, producing around 30.000 deaths (ANCHIETA, 1988), or in São Luís, in Maranhão, in 1621, devastating 27 indigenous villages with a population of around 12.000 (HEMMING, 2007). In some other cases, epidemics came along with the sword and arcabuzes (old shotgun) as part of the war machine, similar to the conquest of the Potiguaras in 1599, following the spread of smallpox by the army led by the Portuguese captain Miguel Álvares Lobo (VICENTE DO SALVADOR, 1982).

During the dictatorship (1964-1985), forced contact with voluntarily isolated peoples, who were still resisting the conquest of their territories by hiding in the forest, provoked deaths of, in general, half of the group population that were contacted. Such events happened among the Matis in the Javari Valley with more then two hundred deaths, according to Turu (2018), the Panara along the BR163 road (two third of the population died, according to CNV, 2014), or, even worse, as with the Kararao and the Xikrin around the Xingu River (CRUZ, 2015). It's the main cause of the 8,350 deaths counted by the National Truth Commission - although cases as the Matis were not counted in the report (TURU, 2018). When the flu reached the recently contacted Arara in the early 1980's, first contacted in efforts to build the Transamazon road and to take them out of the way, the sertanista Wellington Figueiredo told me that the virus quickly spread in the village. The first decision of one of the two Arara group was to escape to the forest to hide away from Funai (National Indian Foundation) officials. The scene he described is disturbing: "On the first day of hiking, we started to see vultures. Vultures surrounding the forest. When we arrived at a village, there were two semi-buried bodies there: one with the shank outside, the other with the arm outside." (FIGUEIREDO, 2015, p. 280). The fate of many of the Arara, one of the thousands of indigenous people killed by disease like flu, was seen as a "natural" effect of contact, and nothing could be done. Another sertanista, Fiorelo Parisi, who led the contact with the Wayapi for the opening of the Perimetral Norte noted that many Wayapi people died after the contact with Funai and with wildcat goldminers. In his words: "When I met Chico Meireles, he told me that, after the contact, around $50 \%$ to $60 \%$ of the Indians died from disease. That was normal, it happened. It does not mean that he didn't care about it, it is not that. There was no other solution at the time, no other thought". (PARISI, 2015, p. 186). The only way to survive was to escape. Megaron Txucarramãe wrote me in a recent chat:

"During the time that Orlando Villas Bôas and his team that made the first contact with us, someone was infected with flu, they crossed the waterfall and went away, very soon our people got flu, Felipe, they initially buried the people, but then they had to leave the bodies and escape, and we went to Kapotnhinore, that's how my father saved 
me. Only my sister died from this flu." 1

All of these mentioned tragedies happened during periods of intense environmental conflicts leading to the dispossession of indigenous peoples from their territories, either in the 16th century with the conquest of Brazil, or the more recent invasion of the Amazon during the dictatorship. "The weapons of conquest," as Darcy Ribeiro has written in his long and famous investigation of the genocide of the first half of the last century in Brazil, "were some appetites and ideas, more efficient equipment for action on nature, bacilli and viruses, especially viruses" (RIBEIRO, 1970, p. 272). The current coronavirus pandemic that is devastating indigenous peoples all over Brazil has again, as with previous epidemics, been mobilized by morbid and greedy appetites and ideas.

The ideology of fascism of the civil-military dictatorship (SANTOS, 1977; FERNANDES, 1981) inspires in part the ideologically fascist government of Jair Bolsonaro, who has made a focused attack on indigenous people ever since his campaign - and as well as on quilombos communities and black people. The coronavirus pandemic has come during a campaign that had already begun to open indigenous territories to conquest for extractive economies, such as agribusiness and mining, by passing different bills to weaken legal protection of indigenous lands, associated with evangelical proselytism for the conquest of indigenous souls (MILANEZ, 2020). It is not rhetoric, or an exaggeration, to name what the indigenous movement has being calling a "politics of extermination": a genocide. As previous experience demonstrates: virus, bacteria and bacilli have been mobilized to open new lands. After the United Nations Convention of 1948, this process is considered an act of genocide. In the public inform published the 20th of May, the Coordination of the Indigenous Organizations of the Brazilian Amazon (COIAB) announced: "There is an institutionalized genocide in Brazil throughout the anti-indigenous policy of Bolsonaro."

Given this long experience of violence, while the news of the coronavirus pandemic was spreading in Brazil, indigenous leaders have been quickly searching for information and starting to build survival strategies. In mid-March, the Kayapo leader Megaron Txucarramãe, who was already having long discussions with leaders to act quickly, wrote me a personal message saying: "We can't play around with this coronavirus sickness. It has the power of the anaconda, death by strangling, the victim unable to breathe and dies." Another problem, he says, is that "eyes cannot see it." Three months before this short talk, in the village of Piaraçu where he leaves, the Kayapo people led by Megaron's famous uncle Raoni received the visit of 450 indigenous leaders from different indigenous peoples for a huge camp for protest and discussions, and at the end they published a manifesto to: "denounce that a political project from the Brazilian government of genocide, ethnocide and ecocide is underway." (APIB, 2020) 


\section{The colonial production of vulnerability}

Disasters and tragedies are extreme events which threaten the existence of communities, and a sociology of disaster exposes the contradictions of capitalism and colonialism associated with socio-environmental effects, such as the social construction of the risks, exposure, vulnerabilities and inequalities of the impacted communities (MILANEZ, 2019). The trajectory of the novel coronavirus (Sars-CoV-2) spreading all over Brazil reveals that the exposure to the virus and the treatment of its infectious effects among human populations has been distributed extremely unevenly. While some people have had privileged access to medical care, equipment to guarantee the right to breath, to access oxygen, other social groups are disproportionately exposed to death, organized by a logic of division structured by social classification. This unequal distribution can be manipulated to control the lives of some groups, while promoting a greater exposure of other specific groups to death, in what Achille Mbembe calls necropolitics (2003).

This social abyss that divides the ones who may live from those left to die appears in landscapes as a colonial wall. The wall separates, as the abyssal line from Boaventura de Sousa Santos (2007), two neighbourhoods in the town of São Paulo, as the abyssal difference of fatality between Morumbi where there were more cases in São Paulo in April, to Brasilândia, a place with more deaths, or Moema, another upper middle class neighbourhood with four times less fatalities than Brasilandia (RODRIGUES et al., 2020). With indigenous peoples infection rates can be $744 \%$ higher than among whites in Brazil, or mortality around 10\% while non-indigenous Brazilians around 6\%. If there is a challenge of where to place the infected whites, in Bahia a hotel near an indigenous land has already been chosen.

Environmental racism, as initially perceived by Robert Bullard, has gained a new dimension with the sanitary crises, even beyond the challenges of Katrina or Dixie. The legacy of Brazilian apartheid exposes the "wrong side of the tracks" where some people receive less attention and different treatment (BULLARD, 1994). "Racial discrimination," the author argues, "limits mobility, reduces neighbourhood and residential options, diminishes opportunities, and subjects millions of Americans to environmental and health threats" (BULLARD, 1994, p. 445).

Racism has been mobilized during the coronavirus pandemic not only to exclude, but to kill and to let die. Institutional racism (CARMICHAEL; HAMILTON, 1967) that pervades state structures and policies is a continuation of colonialism, since racism, colonialism and conquest are inseparable terms, as noted by Aimé Cesaire (1978) and Frantz Fanon (2005). The flexibility of the racist practices that have existed throughout the history of Brazil's social and institutional formation today enables a vigorous re-elaboration and adaptation to the new conjuncture emerging with the coronavirus pandemic (MILANEZ; VIDA, 2020). Governmental responses - in which I include the absence of response through insufficient political actions, and strategic impotence to deal with critical issues, as a general political option to deal with the pandemic - is structured by racism and is producing, while this text is being written, a genocide.

The vulnerability of indigenous peoples and indigenous territories (AZEVEDO et 
al., 2020) is not natural, as the deaths after the forced contact during the dictatorship were not natural. Although many scientists have conducted research since the beginning of the pandemic to demonstrate the vulnerability of specific indigenous lands and indigenous groups in order prevent contagions, theyhave been systematically ignored.

In a letter to Science, in mid-April, Ferrante and Fearnside demanded government action, showing that "COVID-19 poses a particular threat to these communities given that Brazil's federal government has marginalized and neglected Indigenous peoples even when their rights are guaranteed by law or by international agreements" (FERRANDE; FEARNSIDE, 2020, p.251). The authors demanded that the Brazilian government to take urgent action, adding that many of these isolated communities lack medical posts, doctors, basic medications, and the ventilators that would be needed to treat COVID-19."

This last point raised by the authors is very important in terms of analysing the capacity of the state in dealing with epidemic crisis. In the entire state of Amazonas, only the capital Manaus has intensive care units. Mostly of indigenous villages and riverine communities, such as in the Javari Valley and the islands of Marajó archilpelago, were firstly attended by doctors after the program Mais Medicos, from 2013, which brought around 8,000 Cuban doctors to Brazil. Bolsonaro offended the program during his campaign and just before his inauguration promised to carry out a massive expulsion of all Cuban doctors for ideological purposes. Due to the threats, Cuba decided to leave the program. Indigenous peoples were directly affected all over the country. The kayapo village of Gorotire, heavily affected by COVID-19 with four deaths by the last week of May, used to have two Cuban doctors. Two expeditions conducted by Funai in 2014 and 2015 to contact two groups of isolated Korubo indigenous people, in the Javari Valley, had Cuban doctors and a detailed contingency plan and quarantine. There was no disease neither epidemic outbreak reported.

A month after WHO declared a pandemic, different studies have tried to build scenarios of coronavirus infection amid indigenous peoples, in order to prevent and to prepare action from the state. Studies led by a group of researchers from the Universidade Federal de Minas Gerais and Instituto Socioambiental identified 151 indigenous lands that were most vulnerable to coronavirus infections, such as territories invaded by wildcat goldminers in the Amazon (Yanomami and Javari), and those close to cities. This investigation has been published online in order to gain attention from public authorities, and has also been published with an online map of the vulnerability of indigenous land (https://covid19.socioambiental.org/). Their conclusion stresses that "deforestation and illegal mining, as well as illegal invasions and settlements are perceived by indigenous peoples as public health issues" (OLIVEIRA et al., 2020, p 5).

Another report rapidly published to offer input to public policies to prevent contagion in indigenous lands, Azevedo et al. (2020) used data from IBGE, the Ministry of Health and Funai, and the issue of the demarcation of indigenous land, to build another index of vulnerability based on demographics and infrastructure close to indigenous territories. They have used different variables such as Covid-19 transmission rate, mortality among infected individuals, ability to maintain social isolation, to keep a routine of pre- 
vention, availability of Intensive Care Units, and the security of the land regularization situation of the Indigenous Lands. Whether related to invasions and territorial threats, or access to care, information on the possible results of the spread of Sars-CoV-2 were available in civil society. But while researchers were stressing the need to act fast, the federal government has provided a slow and very contradicted response, even not using the available public funds.

Government omission was therefore not related to the lack of reports and information. No enforcement of contingency plan, no information provided from the Special Secretariat of Indigenous Health (Sesai) to indigenous peoples, and an aggressive infodemic have confused many indigenous groups. Indigenous people have taken direct action by themselves, in a deeply uneven way. The Tupinamba in Bahia have been able to contain the situation at least as of the end of May. Since the first days they did so by building dialogue with the community and outsiders and blocking all roads crossing their land early on (MILANEZ, 2020). Megaron, Raoni and the Kayapo Metuktire have also decided to isolate themselves and also have blocked the road crossing Piaraçu village, the MT 322, and the ferryboat to cross the Xingu river. Blockading access of roads and of rivers, such as the strategy of the Yawanawa in the Gregorio River, in the state of Acre, was a first movement of direct action by at least 40 indigenous peoples in more then 17 states, according to a report from Observatório do Agronegócio (BALDUINO, 2020). Even one Kayapo village in Para, Turedjam, decided to shut down an illegal goldmining operation inside their territory. But in general they were unable to organize a supply system that would avoid the need for regular visits to areas near cities, and these strategies have proven difficult to maintain without external support from the state or other allies, especially because of the need for goods for basic survival. The village of Turedjam confirmed the first COVID-19 cases a few days after some villagers went to the city of Ourilandia to receive the government support of $\mathrm{R} \$ 600,00$, where they had to wait for hours in long lines in a public bank and then in the supermarket, while the evangelical church inside the village continued masses every night. The illegal goldmining was reopened after a month, object of a raid from Ibama late April, which appeared on the television with a public reaction from Bolsonaro and the ministry of Environment supporting the miners. After that, a sanitary block to the village became too risky.

When deaths started toward the end of March, Sesai has systematically invisibilized the fate of every indigenous person living in cities and decided not to count deaths inside the territories with people with symptoms but not tested. In response to federal silence and omission, the indigenous movement Network of Indigenous Peoples of Brazil (Articulação dos Povos Indígenas do Brasil, APIB), presented their own information database: the creation of the National Committee for Indigenous Life and Memory (Comitê Nacional pela Vida e Memória Indígena), organizing information received by organizations associated with APIB and based in all territories in Brazil ${ }^{3}$ in association with Abrasco

3- The regional organizations who forms APIB are: Articulação dos Povos Indígenas do Nordeste, Minas Gerais e Espírito Santo (APOINME); Conselho do Povo Terena; Articulação dos Povos Indígenas do Sudeste (ARPINSUDESTE); Articulação dos Povos Indígenas do Sul (ARPINSUL); Grande Assembléia do Povo Guarani (ATY GUASU); COIAB; Comissão Guarani Yvyrupa 
(Brazilian Association of Collective Health) and Midia Ninja, and they published a new website: http://quarentenaindigena.info/apib/. The result is astonishing: the difference between federal data to the investigation of indigenous movement is abyssal. By June 11, while 264 deaths among 97 different indigenous peoples were registered by the Committee, the Federal Government counted only 89 deaths. The deaths of 175 indigenous individuals were ignored. This is not the case of general underreporting, which can be 14 times higher than reality, as the COVID-19 Brasil research group have estimated ${ }^{4}$. It's pure political: Sesai does not consider cases of indigenous peoples living in the cities. In the same time, there has been growing reports of indigenous individuals dying in the villages without testing, as they are also refusing to go to hospitals due to racism and fear that in case of death, their body won't return to funerals ${ }^{5}$.

Going online was one strategy to raise public attention, and in the last week of April, when the Free Land Camp was scheduled to take place in Brasilia with 4,000 indigenous representatives, many live debates and round tables appeared on social media. Different manifestos were written and disseminated directly from affected communities. Alongside scientific alerts, indigenous peoples were mobilized to tell society the risk they were exposed to, something that has not happened during previous epidemic experiences.

\section{The systematic use of the virus to produce death: a genocide}

Among the acts that characterize the crime of Genocide according to the United Nations Convention on the Prevention and Punishment of the Crime of Genocide, from 1948: "Deliberately inflicting on the group conditions of life calculated to bring about its physical destruction in whole or in part". The new UN Special Rapporteur on the Rights of Indigenous Peoples, José Francisco Cali Tzay, of the Maya Kaqchikel people of Guatemala, whose former president Efraín Ríos Montt was convicted of genocide, has a long career in the social and judicial struggle against racism in his country. In his first official statement at the UN, he stressed that "Covid-19 is devastating the world's indigenous communities and it's not just about health".

The National Truth Commission recognized, in its final report, the responsibility for the death of 8350 indigenous individuals by the State, the destruction of indigenous lands and the violation of rights "by direct action or omission". The crime of Genocide is not characterized by the number of people killed, nor by the express manifestation of the genocidal intent, but by the commissive or omissive way the actions are undertaken and by their objective effects. One or a few deaths produced with the interest of exterminating a group affects the whole existential dynamics of the group, directly and indirectly, damaging its autonomy, weakening its political participation and its strategies of cultural resistance, contributing to its identity disintegration and physical disappearance.

4- COVID-19 BRASIL: Análise Subnotificação. Available from: https://ciis.fmrp.usp.br/covid19/analise-subnotificacao/ Access in 4th June 2020.

5- Ongoing investigation of such cases have been reporterted with the Kayapo in the state of Para and documented with the research project Mapping Indigenous Rights Abuses, coordinated by the author in a research network. 
While the pandemic ravaged indigenous lands, federal government issued different legal measures to dispossess indigenous people's land and to facilitate and easily land grabs, either administrative measures in Funai, or new bills sent to the Congress. The deaths and terror in the indigenous territories has been transformed into an opportunity of conquest for capital and the rural elite. Colonization is essentially the denial of the other, which can appear as a more subtle form or even subjective of interpersonal, to a physical elimination of individuals and collectives. Colonization and racism are associated, in the case of indigenous people in Brazil, to their original right to the traditional occupied land (MILANEZ et al., 2019).

The political ecology of this current genocide in Brazil reveals the association of structural racism, which is dividing the right to breathe and to live through the access of medical care and excluding indigenous peoples and blacks, with the economic interests in the exploitation of natural resources. It's not new. It's colonialism. Fanon had identified the perfect correlation between economics and ideology in a racist society: "The racist in a culture with racism is therefore normal. He has achieved a perfect harmony of economic relations and ideology." (1967, p. 40)

Coronavirus may have been used to clear indigenous territories from its people to land grabbers and extractive economies. As the chief of the Megaron told me in the same dialogue previously mentioned:

I will open a new village to stay away from movements, as happens in Piaraçu. We are on the board of the MT 322. I want to stay away from the road, going to Kapotnhinore where my father took me in the past, and start to grow a new traditional farm with our crops and harvest. I will camp by the right margin of the Xingu river. That's where the Metuktire used to cross to Kapotnhinore. I will be isolated. I will wait for the coronavirus to go away. ${ }^{6}$

Again as in past epidemics, to survive is to resist, and in order to survive, many will have to be able to escape: escape from coronavirus and from the violence of the state.

\section{Acknowledgment}

A special thank to Megaron Txucarramãe, Matavitsa Kena Waura Txucarramãe, Matsipaya Bepkoti Beppakrejti Waura Txucamarrãe and Raoni Metuktire. I also would like to thank Mary Menton (U. Sussex), Jurema Machado (UFRB), Felipe Tuxá (UNEB) and colleagues of the research project Mapping Indigenous Rights Abuses in Northeastern Brazil, funded by the University of Sussex.

6 - Megaron Txucarramãe, personal communication, whatsapp, 2020. Translated by the author. 


\section{References}

ANCHIETA, J. Cartas, Informações, Fragmentos Históricos e Sermões (1554-1594). Belo Horizonte: Itatiaia; São Paulo: Edusp, 1988.

ARTICULAÇÃO DOS POVOS INDÍGENAS DO BRASIL. Manifesto of Piaraçu, January 20th 2020. Available from: http://apib.info/2020/01/20/manifest-of-piaracu/?lang=en Access in May 20th 2020.

AZEVEDO, M. DAMASCO, F., ANTUNES, M., MARTINS, M. H., REBOUÇAS, M. P. Análise de Vulnerabilidade Demográfica e Infraestrutural das Terras Indígenas à Covid 19. Caderno de insumos. Campinas: NEPO-Unicamp, 2020.

BRASIL. Comissão Nacional da Verdade. Relatório. Volume II. Textos temáticos. Brasília, 2014.

BULLARD, R. D. The Legacy of American Apartheid and Environmental Racism, Journal of Civil Rights and Economic Development. V. 9, n. 2, pp. 445-474, 1994.

CARMICHAEL, S; HAMILTON, C. Black power: the politics of liberation in America. New York, Random House, 1967.

CÉSAIRE, Aimé. Discurso sobre o colonialismo. Livraria Sá da Costa, Lisboa, 1978.

CRUZ, A. Depoimento, In MILANEZ, F. Memorias Sertanistas: Cem Anos de Indigenismo no Brasil (org.) São Paulo: Sesc, 2015, p. 113-138.

FANON, F. Toward the African Revolution: Political Essays. Grove Press, 1967. . Os Condenados da Terra. Editora Universidade Federal de Juiz de Fora, 2005.

FERNANDES, F. Poder e contrapoder na América Latina (3 $3^{\text {a }}$ edição). Rio de Janeiro: Zahar, 1981.

FERRANTE, L.; FEARNSIDE, P. Protect Indigenous peoples from COVID-19. Science, v. 368, i. 6488, p. 251, 2020.

FIGUEIREDO, W. Depoimento, In MILANEZ, F. Memorias Sertanistas: Cem Anos de Indigenismo no Brasil (org.) São Paulo: Sesc, 2015, p. 251-284.

MBEMBE, A. Necropolitics. Public Culture, v.15, i. 1, p. 11-40, 2003.

MILANEZ, F. Memorias Sertanistas: Cem Anos de Indigenismo no Brasil (org.) São Paulo: Sesc, 2015.

MILANEZ, F, (2019), "Desastre", Dicionário Alice. Consultado em 20.05.20. Available from :

https://alice.ces.uc.pt/dictionary/?id=23838\&pag=23918\&id_lingua $=1$ \&entry $=24249$. Access in: June 42020.

MILANEZ, F.; SÁ, L.; KRENAK, A.; CRUZ, F; URBANO, E. e PATAXÓ, G. Existência e Diferença: O Racismo Contra os Povos Indígenas. Direito \& Praxis, Rio de Janeiro, v.10, n.3, p.2161-2181, 2019. 
MILANEZ, F. Bolsonaristas tentam quebrar quarentena de indígenas a tiros. Carta Capital, April 3rd 2020. Disponível em: https://www.cartacapital.com.br/sociedade/bolsonaristas-tentam-quebrar-quarentena-de-indigenas-com-tiros/ Access in: May 20th 2020.

MILANEZ, F; VIDA, S. Pandemia, racismo e genocídio indígena e negro no Brasil: coronavírus e a política de extermínio. Clacso: Pensar la pandemia: Observatório social del coronavírus. Available from: https://www.clacso.org/pandemia-racismo-e-genocidio-indigena-e-negro-no-brasil-coronavirus-e-a-politica-de-exterminio/ Access in: May 20th 2020.

HEMMING, J. Ouro Vermelho. São Paulo: Edusp, 2007.

SANTOS, T. dos. Socialismo y fascismo en América Latina hoy. Revista Mexicana de Sociología, v. 39, n. 1., p. 173-190, 1977.

SOUSA SANTOS, B. Beyond Abyssal Thinking: From Global Lines to Ecologies of Knowledges. Review, XXX, 1, 45-89, 2007.

OLIVEIRA, U.; SOARES Fo․, B.; OVIEDO, A.; MOREIRA, T.; CARLOS, S.; RICARDO, J.; PIAZ, A. Modelagem da vulnerabilidade dos povos indígenas no Brasil ao covid-19. São Paulo: Instituto Socioambiental, 2020.

PARISI, F. Depoimento, In MILANEZ, F. Memorias Sertanistas: Cem Anos de Indigenismo no Brasil (org.) São Paulo: Sesc, 2015, p. 169-188.

RIBEIRO, D. Os índios e a civilização. São Paulo: Vozes, 1970.

RODRIGUES, R.; BORGES, B.; FIGUEIREDO, P. Morumbi tem mais casos de coronavírus e Brasilândia mais mortes. G1, April 18th 2020. Available from: https:/g1.globo.com/sp/sao-paulo/ noticia/2020/04/18/morumbi-tem-mais-casos-de-coronavirus-e-brasilandia-mais-mortes-obitos-crescem-60percent-em-uma-semana-em-sp.ghtml Access in: May 20th 2020.

TURU, M. Nós indígenas precisamos ser ouvidos diretamente e ser reparados das violações que sofremos Tipití: Journal of the Society for the Anthropology of Lowland South America: Vol. 16: Iss. 1, Article 14, 158-163, 2018.

TXUCARRAMÃE, M. Personal communications. Whatsapp. March19th; March 23rd; April 9th; May 20th 2020.

VICENTE DO SALVADOR. História do Brasil: 1500-1627. 7 ed. Belo Horizonte: Itatiaia; São Paulo: Editora da Universidade de São Paulo, 1982. 


\section{Felipe Milanez}

$\square$ felipemilanez@ufba.br

ORCiD: https://orcid.org/0000-0001-6176-2410
Submitted on: 06/06/2020

Accepted on: 08/06/2020

2020;23:e0116

How to cite: MILANEZ, F. Fighting the invisible anaconda amidst a war of conquest: notes of a genocide. Ambiente \& Sociedade. São Paulo, v. 23, p. 1-11, 2020. 


\title{
Lutando contra a sucuri invisível em meio a uma guerra de conquista: apontamentos de um genocídio
}

\author{
Felipe Milanez
}

São Paulo. Vol. 23, 2020

Ideias em debate

A época CO. VID-19: Pesquisa interdisciplinar e uma nova ética sustentável e justa
Resumo: A conquista dos territórios indígenas e doenças epidêmicas sempre andaram lado a lado ao longo da história do Brasil. A atual pandemia do novo coronavirus que está devastando comunidades indígenas segue essa violenta estratégia de conquista. Meu argumento é que o racismo estrutural que conduziu a mais de 200 mortes de pessoas indígenas nos primeiros meses da pandemia deve ser visto não como resultado de atos irresponsáveis de omissão, mas como atos de genocídio.

Palavras-chave: Povos Indígenas, coronavírus, conquista, genocídio, ecologia política

Como citar: MILANEZ, F. Lutando contra a sucuri invisível em meio a uma guerra de conquista: apontamentos de um genocídio. Ambiente $\mathbb{E}$ Sociedade. São Paulo, v. 23, p. 1-11, 2020.

DOI: http://dx.doi.org/10.1590/1809-4422asoc20200116vu2020L3ID 


\title{
Luchando contra la anaconda invisible en medio de una guerra de conquista: notas de un genocidio
}

\author{
Felipe Milanez
}

São Paulo. Vol. 23, 2020

Ideas en debate

La época CO. VID-19: investigación interdisciplinaria y una nueva ética sostenible y justa
Resumen: La conquista de los territorios indígenas y las enfermedades epidémicas siempre han ido de la mano a lo largo de la historia de Brasil. La pandemia actual del nuevo coronavirus que está devastando a las comunidades indígenas sigue esta estrategia de conquista violenta. Mi argumento es que el racismo structural que produjo más de 200 muertes de indígenas en los primeros meses de la pandemia no debe verse como actos de omisión irresponsables, sino como actos de genocidio.

Palabras clave: Pueblos indigenas; coronavirus; conquista; genocídio; ecología política

Como citar: MILANEZ, F. Luchando contra la anaconda invisible en medio de una guerra de conquista: notas de un genocidio. Ambiente $\mathbb{E}$ Sociedade. São Paulo, v. 23, p. 1-11, 2020.

DOI: http://dx.doi.org/10.1590/1809-4422asoc20200116vu2020L3ID 